\title{
Frei exemplo é o melhor educador*
}

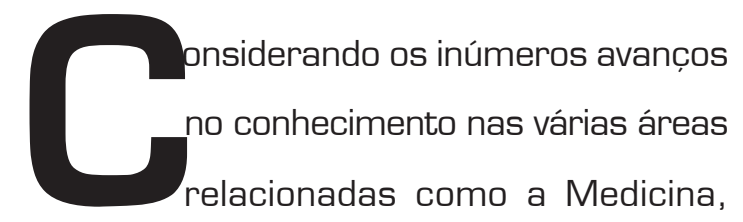

ocorridos nos últimos 50 anos que tem contribuído para o exercício da medicina e profissões afins, o corpo Editorial da Revista Medicina decidiu iniciar uma nova sessão de artigos dedicada a registrar depoimentos e reflexões de profissionais de saúde e de pesquisadores que vivenciaram o desenvolvimento do conhecimento nas suas áreas de atuação ao longo de décadas de experiência. Pretendemos que esta iniciativa possa inspirar e estimular jovens profissionais ou acadêmicos no desenvolvimento de suas carreiras.

Neste volume, o Prof. Dr. Milton Luiz Gorzoni, Professor Adjunto do Departamento de Clínica Médica da Faculdade de Ciências Médicas da Santa Casa de São Paulo, nos traz uma narrativa sobre o desenvolvimento do ensino e da assistência voltada ao paciente idoso no Brasil.
O professor Gorzoni obteve seu título de especialista em Geriatria e Gerontologia pela Associação Médica Brasileira e pela Sociedade Brasileira de Geriatria e Gerontologia em 1987, acumulando, desta forma, cerca de 30 anos de experiência médica nesta ainda jovem especialidade médica. Seu artigo irá propiciar ao leitor um histórico do desenvolvimento da Geriatria no Brasil e no Mundo e suas reflexões pessoais apontam os possíveis caminhos da especialidade no futuro e, em especial, sua inserção no Sistema Unificado de Saúde brasileiro. Com este artigo inicial, esperamos receber mais contribuições semelhantes que iremos selecionar e publicar nos próximos números da Revista Medicina. Desta forma apreciaríamos sugestões de temas e de personalidades que possam usufruir deste espaço para registrar suas experiências. Tais sugestões podem ser endereçadas ao email da revista ${ }^{1}$. Esperamos que tenham uma excelente e proveitosa leitura.

Prof. Dr. Eduardo Barbosa Coelho

Prof. Dr. Gustavo Ballejo Olivera

Prof. Dr. Wilson Salgado Júnior

Corpo Editorial da Revista Medicina

*Dito popular português.

1.revmed@hcrp.usp.br 